\title{
Solidarity and Sovereignty: The Two-Dimensional Game of Swedish Security Policy
}

\author{
By Magnus Christiansson *
}

\section{Introduction}

The purpose of this article is to analyze and interpret the Swedish security policy discourse related to the Defense Bill of 2009 (Inriktningspropositionen) ${ }^{1}$. The Defense Bill could be regarded as a key policy document for the development of Swedish defense over the following decade. One of the most puzzling features of this piece of legislation is its emphasis on solidarity within the EU and Nordic region (in political as well as in military terms) while maintaining the policy of avoiding NATO membership. This has stirred a debate about the interpretation of the Swedish policy². How should we understand this militarily non-aligned country that declares military solidarity with its neighbors? The conclusion of this analysis is that the current Swedish security policy discourse should be interpreted as a two-dimensional game of solidarity and sovereignty, and that this perspective challenges the notion that a change of identity is necessary for a lasting change in security policy.

The fundamental framework of this article is rooted in the idea that every country has a distinct strategic culture. ${ }^{3}$ The interest in strategic culture is motivated, not least, by the fact that the end of the Soviet empire triggered quite different security policies among the countries in the Nordic-Baltic area. What is considered to be a serious defense proposition in Helsinki is regarded as something of a joke in Copenhagen. ${ }^{4}$ Thus, a focus on systemic change is not the only interesting approach; an examination of cultural change can offer insights as well.

* Magnus Christiansson is a Senior Lecturer in the Department of Strategy at the Swedish National Defense College in Stockholm.

1 Regeringen, Ett användbart försvar Prop 2008/09:140.

2 Two examples include Bo Hugemark, "Sverige måste kunna försvara sina grannar," Svenska Dagbladet (29 January 2009); and Claes Arvidsson, "En värld - två alternative,"Svenska Dagbladet (18 February 2010).

3 Strategic culture is introduced in Jeffrey S. Lantis \& Darryl Howlett, "Culture and National Security Policy," in Strategy in the Contemporary World, 3rd. ed., eds. John Baylis, James J. Wirtz \& Colin S. Gray (Oxford: Oxford University Press, 2010), 84-103. The relationship between strategic culture and more established research traditions is covered in John Glenn, Darryl Howlett, \& Stuart Poore, eds., Neorealism Versus Strategic Culture (Aldershot, U.K.: Ashgate, 2004). Note that the assumption of strategic culture on a national level does not mean that strategic cultures are national by definition.

4 For an overview of Nordic strategic culture, see Cooperation \& Conflict 40:1 (2005). 
However, the analytic components of any given strategic culture are far from obvious. There are several challenges for the study of cultures in general, as well as strategic cultures in particular. ${ }^{5}$ This article takes the theoretical assumption that strategic culture is both structure and process. Individuals live in a strategic culture, and also use strategy culturally for different purposes. ${ }^{6}$ Change in a strategic culture is not a spontaneous process since, in the words of Hans-Georg Gadamer, "the process of construal is itself already governed by an expectation of meaning that follows from the context of what has gone before." 7 The methodological logic that follows from this is that language, with its symbols and codes, is a reflection of meaning. ${ }^{8}$ In this way, the study of the debate following the Defense Bill of 2009—or indeed in the words of philosopher Paul Ricoeur, of "any discourse fixed by writing" — is a method to trace the meaning of strategic language within Sweden's strategic culture.

Thus, for the purpose of this text, the term discourse is defined as "a system for the formation of statements" about security issues. ${ }^{10}$ The key structure under examination in this article is the Defense Bill of 2009 which, together with the Defense Commission (Försvarsberedningen), constitutes the focal point for my analysis. The Defense Bill is the official policy of the Swedish government, and the Defense Commission is a preparatory forum with representatives from all political parties in the parliament as well as external experts. It must be noted that the security policy discourse features elements of both defense policy and foreign policy. ${ }^{11}$

5 This is mirrored by the Gray-Johnston debate. On the one hand, strategic culture is regarded as context that shapes and provides meaning to strategic actions. On the other hand, strategic culture is regarded as one variable among several that explain strategic actions. For an introduction and comment on the Gray-Johnston debate, see Stuart Poore, "What Is the Context? A Comment on the Gray-Johnston Debate on Strategic Culture," Review of International Studies (2003): 279-84.

6 This approach to culture is in line with the hermeneutic historians at Lund University. See Klas-Göran Karlsson \& Ulf Zander, eds., Echoes of the Holocaust: Historical Cultures in Contemporary Europe (Lund: Nordic Academic Press, 2003), 32.

7 Quoted in ibid., 13.

8 The roots of this approach could be traced to Gadamer. see Hans-Georg Gadamer, Truth and Method (New York: Continuum, 1993).

9 Quoted in Karlsson \& Zander, Echoes of the Holocaust, 13.

10 Iver B. Neumann \& Henrikki Heikka, "Grand Strategy, Strategic Culture, Practice" in Cooperation \& Conflict 40:1 (2005): 11.

11 This heuristic divide is inspired by Kjell Engelbrekt \& Jan Ångström, eds., Svensk säkerhetspolitik $i$ Europa och världen (Stockholm: Norstedts Juridik, forthcoming). Engelbrekt and Angström argue that security policy is defined by the activities of the Defense Ministry and the Foreign Ministry. 
However, I will not devote myself to discursive practices, which include capability development or policy implementation in the security policy field. In this sense, the findings of this article are focused on determining the conditions for strategic action. In other words, to get the whole picture, one must also study strategic practices.

The structure of the article is as follows. First, I will describe the theoretical elements of two-level or two-dimensional games. The hypothesis introduced in this section is that the Swedish government is involved in a two-dimensional game in order to protect its perceived interests internationally while avoiding the political controversies associated with alliance policies within Swedish strategic culture. Second, I will analyze the discourse around the Defense Bill of 2009 related to the concept of solidarity. I show how the declaration of solidarity is a result of conceptual stretching that is beneficial for flexible foreign policy action as well as satisfying traditionalists within Sweden's strategic culture. Furthermore, this section displays how this conceptual stretch challenges the traditional understanding of solidarity, and discusses its policy implications. Third, I will analyze the discourse around the Defense Bill of 2009 related to issues of sovereignty. We will see how the government engaged in a game that tried to maintain the image of sovereignty as a traditional national concern, while simultaneously widening the meaning of sovereignty to fit an international context. Finally, I will summarize my main conclusions regarding the Swedish security policy discourse as a two-dimensional game. The findings of this article challenge the notion that a change in identity is necessary for a long-term change in security approach.

\section{Two-Dimensional Games}

One of the traditional features of Swedish security policy theory is the analytic differentiation of the Siamese twins, domestic policy and foreign policy. Admittedly, in the seminal study Säkerhetspolitik (Security Policy), the acclaimed scholar Nils Andrén notes that it is difficult to make a clear distinction between the two. ${ }^{12}$ Not only can foreign policy initiatives undermine defense policy, but defense policy can have consequences on foreign policy as well. There are many cases where the domestic agenda and the foreign policy agenda do not precisely align, and may actually oppose each other.

In 1988, political scientist Robert Putnam offered a theoretical approach to deal with the questions of when and how domestic policy influences diplomacy. ${ }^{13}$

12 Nils Andrén, Säkerhetspolitik - Analyser och tillämpningar, andra upplagan (Stockholm: Norstedt Juridik, 2002), 30.

13 Robert D. Putnam, "Diplomacy and Domestic Politics: The Logic of Two-level Games," International Organization 42:3(Summer 1988): 427-60. 
Following his study of the 1978 Bonn Summit, he noted the appearance of what he called a two-level game. He concluded something that now seems rather obvious: international negotiations could involve more negotiation efforts domestically than internationally, which challenges the view of the state as a unitary international actor. Among other things, this opened up the possibility for a better understanding of ratifications of international agreements. A state can be forced to make an involuntary defection from international agreements because of a failure to convince domestic actors.

Arguably, since Putnam based his article on game theory, it was difficult to handle situations that were not clearly negotiations or bargaining sessions. Thus, to him, the metaphor of a "game" was primarily related to the meaning of "match" or "gambling." However, it is quite possible to imagine a perspective in which "game" has the simultaneous meaning of "drama" and "play" as well. The argument is that the notion of a "game" could have a double meaning, one that relates to interests as well as identities. This latter perspective opens the possibilities for a study of how national strategy can be used to communicate in pursuit of several purposes and motives.

The Danish scholars Rebecca Adler-Nissen and Thomas Gammeltoft-Hansen have developed the metaphor of what they call "sovereignty games."14 Due to (inter alia) globalization and the use of military capabilities outside state territory, "what emerges is an expansion of the playing field relating to sovereignty." 15 This, AdlerNissen and Gammeltoft-Hansen argue, creates a situation where core functions of the state are outsourced while diplomats and statesmen enter a tricky political game "to simultaneously allow international cooperation and communicate a sense of sovereignty to the domestic audience." 16 Thus, the game becomes a set of "strategic maneuvers" motivated by both interests and identities. ${ }^{17}$ This framing invites a dual understanding of a discourse-one related to the international arena and one related to the domestic arena. ${ }^{18}$

The key characteristic of the international game is policies that disconnect state power from sovereign territory. In the present context, this process has often had the label "Europeanization," and it has related to everything from immigration control to foreign policy.

14 Rebecca Adler-Nissen \& Thomas Gammeltoft-Hansen, "An Introduction to Sovereignty Games," in Sovereignty Game: Instrumentalizing State Sovereignty in Europe and Beyond, eds. Rebecca Adler-Nissen \& Thomas Gammeltoft-Hansen (New York: Palgrave Macmillan, 2008).

15 Ibid., 2.

16 Ibid.

17 Ibid., 10.

18 Note that these dimensions are not synonymous with the "horizontal games" and "vertical games" used by Adler-Nissen and Gammeltoft-Hansen. 
The key dynamic in this game is that "states engage in conceptual stretching," since there are both domestic and international constraints in place influencing state policy decisions. ${ }^{19}$

The key characteristic of the domestic game is policies that enhance state autonomy in an international environment. In the Swedish context, this is related to the core tasks of Swedish defense and security policy as well as the search for legitimacy for specific policies. The key dynamic of this game is that "national executives are playing on the legal and symbolic arsenal provided by the conceptual framework of sovereignty." 20

In her case study comparing the Danish and British decisions to opt out of the EU integration process, Adler-Nissen used these two dimensions as different aspects of a sovereignty game. ${ }^{21}$ Both countries have exceptions from the Maastricht treaty, which has put pressure on state representatives to circumvent these opt-outs with reference to national interests while maintaining respect for public opinion. The driver of this double-edged process when state officials circumvent opt-outs is "to reduce their exclusionary effects, so the figure of an autonomous state is preserved at home despite its entanglement in the European integration process." 22

The hypothesis is thus that the traditional lack of an alliance policy in the Swedish strategic culture represents such an "opt-out" from the European integration process. According to the Lisbon Treaty, its mutual assistance clause "shall not prejudice the specific character of the security and defense policy of certain Member States." 23 This opens similar opportunities for a two-dimensional game like those described by Adler-Nissen. The Swedish government tries to protect its perceived interests in the international process of security integration, while maintaining the domestic image of Sweden as a militarily non-aligned country with full freedom of action. The political rationale for this hypothesis is that the Swedish government wants to be a part of the continued security integration process but also hopes to avoid the domestic political controversies associated with alliance policies in the Swedish context. Developing a study of Swedish security policy from this perspective fits with earlier calls for

19 Adler-Nissen \& Gammeltoft-Hansen, “An Introduction to Sovereignty Games," 14.

20 Ibid., 12.

21 Rebecca Adler-Nissen, "Organized Duplicity? When States Opt Out of the European Union," in Sovereignty Games: Instrumentalizing State Sovereignty in Europe and Beyond, ed. Rebecca Adler-Nissen \& Thomas Gammeltoft-Hansen (New York: Palgrave Macmillan, 2008), 81-104.

22 Ibid., 100.

23 Consolidated Treaty on the European Union, Article 42(7). 
research on the frequent conceptual stretching of neutrality and the development of national identity as well as political language. ${ }^{24}$

This discursive operation does not have to involve any Orwellian "double speak," since the same rhetoric can have two meanings. In other words: a two-dimensional game does not necessarily turn an actor into a Dr. Jekyll and Mr. Hyde character. The official policy can have one meaning in a domestic debate about defense, and a rather different connotation during international discussions in Brussels and Washington. The importance of this is that security doctrine does not necessarily need to involve a trade-off between domestic and international dimensions.

These dual dimensions can be identified in the Defense Bill of 2009, which expresses the tasks that the Swedish government has set for Sweden's defense forces. From 2010, the tasks of the armed forces are "to defend and promote security, alone and together with others, nationally and internationally." ${ }^{25}$ Analytically, this creates four strategic cases: to defend the country alone; to act alone abroad; to defend the country together with others; and to act abroad together with others. Since the Defense Bill of 2009 features tasks that demand unilateral defense actions as well as action with others, it displays the inherent duality for a militarily non-aligned country engaged in a process of security integration. The tasks relate clearly to the issue of sovereignty (the ability of a state to defend and control its territory) as well as the issue of solidarity (the "Three Musketeers" principle of all for one and one for all).

In the two following sections I will study these two game dimensions within Sweden's security discourse. In the first, I will look closer at the solidarity dimension. We will see how this game is influenced by conceptual expansions that serve as circumventions as well as refuges for actors with an interest in maintaining military non-alignment. However, the changing meaning of solidarity also poses many challenges for policy. The following section will turn to the sovereignty dimension. Here we will note the recurring patterns of reassurance for a domestic audience.

24 See Johan Eliasson, "Traditions, Identity and Security: The Legacy of Neutrality in Finnish and Swedish Security Policies in Light of European Integration," European Integration online Papers 8:6 (2004): 13.

25 Regeringen, Ett användbart försvar, Prop. 2008/09:140, 33. 


\section{The Solidarity Dimension}

\section{The Conceptual Stretching of Solidarity}

One of the most striking features of the Swedish Defense Bill of 2009 is the declaration of solidarity. It states that "Sweden's security is built in solidarity and cooperation with other countries," ${ }^{26}$ and that " $[t]$ he security of the country is not just protected on our own borders." ${ }^{27}$ Following the report of the Defense Commission of 2008, the government declared:

Sweden will not remain passive if a catastrophe or attack should hit another mem ber country or Nordic country. We expect these countries to act similarly should Sweden be hit. Sweden should have the ability to give and receive military support. ${ }^{28}$

As early as 2004, the Defense Commission declared its dedication to a form of solidarity that could include military support after a terrorist attack or natural disaster. ${ }^{29}$ The Commission referred explicitly to the declaration made by the EU Council in March 2004, after the terrorist attack in Madrid. This solidarity is expressed in the Treaty of the Functioning of the European Union (TFEU) as Article 222. Interestingly, in the Swedish Defense Bill of 2004, even if the same declaration of solidarity was made, there was no reference to military support. Both documents concluded that there was no contradiction between solidarity in crisis management and military non-alignment.

However, even though the Defense Commission and the Defense Bill of 2004 introduced a declaration of solidarity, it is misleading to draw the conclusion that the concept of neutrality was absent from the discourse. The Left Party in Sweden used neutrality as an argument against any further military alignment with the EU. ${ }^{31}$ It is also interesting that it was a representative from the Left Party that highlighted a lack of analysis of the EU's constitutional clause on mutual assistance in the event of an armed attack.

26 Prop. 2008/09:140, 9.

27 Ibid., 8.

28 Ibid., 29 [author's translation]. Regarding giving and receiving military support, the term "shall" is used on page 35. See also Regeringen, Försvar $i$ användning, Ds 2008:48, 16.

29 Regeringen, Försvar för en ny tid, Ds 2004:30, 39-40.

30 Regeringen, Vårt framtida försvar, Ds 2004/05:5, 23.

31 Regeringen, Säkerhet i samverkan, Ds 2007:46, 51-52. Expressed by Left Party representative Gunilla Wahlén. 
How could there be no contradiction between solidarity and military non-alignment if solidarity was also to include assistance in cases of armed attack? ? $^{32}$ This latter clause is expressed in Article 42(7) of the Consolidated Version of the Treaty on the European Union.

The Defense Commission of 2007 expanded the declaration of solidarity to include Sweden's Nordic neighbors Iceland and Norway, but still had a reference to the 2004 events in Madrid. Thus, the text still connected solidarity to the growing threat of global terrorism. The Defense Commission of 2008 used the same declaration of solidarity, but with no reference to the events in Madrid. ${ }^{34}$ The meaning of solidarity was expanded so that "Sweden can contribute with military support in catastrophes and conflict situations." ${ }_{4}$ Thus, in the Defense Commission of 2008 there was no longer any explicit reference to solidarity under the meaning of Article 222. Rather, the meaning had changed, so that it included scenarios ranging from crisis management to conflicts involving the use of military forces, and a scope that also included NATO countries.

The Defense Bill of 2009 referred to the Swedish Parliament's ratification of the Lisbon Treaty on 20 November 2008. ${ }^{35}$ It concluded that the declaration of solidarity means that "Sweden will receive and give military support in another way than previously." 36 So even though the phrases of the declaration had been established, their usage was announced as a change. Thus, the new discursive pattern challenged the established meaning of the declaration of solidarity. The connection between solidarity, military support, and Article 222 within the EU was expanded and supplemented by solidarity, military support, and Article 42(7) within the EU, and also including Norway and Iceland.

The confusion that followed in the debate on the Defense Bill of 2009 shows how this continuing process of conceptual stretching between 2004 and 2009 served as both tool and shelter for different actors in Sweden's strategic culture. Defense analyst Stefan Ring has written an interesting analysis that points to a general tendency to make two different interpretations. ${ }^{37}$

\footnotetext{
2 Ds 2004:30, 178-79. Expressed by Left Party representative Berit Jóhannesson.

Ds 2007:46, 11.

Ds 2008:48, 16.

Ds 2008/09:140, 9.

Ibid., 1.

37 Stefan Ring, "Solidaritetsförklaringen," Speech at the AFF and "People and Defense" conference on the declaration of solidarity (3 March 2010); available at http://aff.a.se/20100303. pdf.
} 
The first interpretation is based on the notion that Sweden can keep full freedom of action in foreign policy. According to this interpretation, the meaning of the declaration of solidarity is that it refers strictly to terror attacks according to Article 222. ${ }^{38}$ The second interpretation is based on reciprocity, and holds that any credibility behind a declaration of solidarity lies in making practical preparations for armed attacks according to Article 42(7). ${ }^{39}$

This ambiguity of the declaration of solidarity in the Defense Bill of 2009 has the function to allow a certain flexibility within Swedish foreign policy rhetoric. In Sweden's Parliament, on 17 February 2010, the foreign minister presented a Swedish security policy doctrine that avoided the negative definition of military non-alignment:

... membership in the European Union means that Sweden is a part of a political alliance and takes a solidaric responsibility for the security of Europe. Sweden will not remain passive if a catastrophe or attack should hit another [EU] member country or Nordic country. We expect these countries to act similarly should Sweden be hit. ${ }^{40}$

It is notable that any precise wording regarding the ability to give and receive military support was absent. This statement is, among other things, an emphasis of the civilian aspects of Swedish security doctrine; it simultaneously avoids disturbing those within the Swedish strategic culture who believe in full freedom of action and solidarity according to Article 222. In Helsinki on 4 March 2010, Sweden's foreign minister presented his view on the ongoing process to form a future strategic concept of NATO:

First - let me just stress how important the Article V commitment that is at the core of the Alliance is for all of Europe. There is no doubt that it was of utmost importance during the most critical period of that dark phase of Europe's history that came to an end in 1989. Let us be clear: this was of fundamental importance also to Sweden during those decades when our aim was to make it possible for us to remain neutral in a new European or world-wide conflict.

38 See for example statements by Nils Daag on the topic "The Lisbon Treaty - What is Changing?" at the 2010 People and Defense Annual National Conference.

39 See for example Bo Hugemark \& Johan Tunberger, Trovärdig solidaritet? Försvaret och solidaritetsförklaringen (Stockholm: Stiftelsen Den Nya Välfärden, 2010).

40 Regeringen, Regeringens deklaration vid 2010 års utrikespolitiska debatt i Riksdagen den 17 februari 2010, UD 2010, 2. 
And let us also be clear about how important this remains to all of Europe also today. The security it gives to the members of the Alliance contributes to the stability of a much wider area-including the entire Nordic and Baltic area. Thus, when I hear that there will be a renewed emphasis also on the Article V commitments in the strategic review underway. I can only welcome this. ${ }^{41}$

This statement is, among other things, a clear expression regarding the importance of military solidarity in the Euro-Atlantic area. Sweden's policy of neutrality was always dependent on military alliance commitments across the Atlantic, and the statement underlines the continued importance of the stability provided by such commitments. But the declaration of solidarity also provides a policy refuge for those that embrace security integration within the EU while stressing Sweden's continued freedom of action in a crisis response. Using the EU as a security cooperation platform does not restrain Sweden's foreign policy. According to this logic, participation in structures of deeper military cooperation is important for the general influence it gives Sweden, while becoming involved in the defense planning of other countries is categorically out of the question. The spokesperson for the Social Democrats argued in 2004 for the importance of military cooperation within the EU: "If there is a crisis and the EU has to provide troops, the question is passed around the table. Any nation that does not raise its hand will be regarded as [a] lightweight, in other political issues as well." 42

In 2010, the same spokesperson made a passionate case for not participating in the defense planning of the Baltic States. ${ }^{43}$ Thus, according to this view, Sweden should continue to be an active player in the European security arena while maintaining its military non-alignment. There have been many signals from the Social Democrats that the declaration of solidarity does not necessarily obligate Sweden to make any commitments in military terms. ${ }^{44}$ Solidarity in military terms is a choice, not an obligation.

41 Carl Bildt, "Common Challenges Ahead," remarks at the Seminar on a Comprehensive Approach to Crisis Management within the Debate about NATO's New Strategic Concept, Helsinki (4 March 2010).

42 Mikael Holmström, "Försvarets bantning ger stort manfall," Svenska Dagbladet (28 November 2004).

43 TT, "Het debatt om försvarspolitiken," (17 February 2010). [Author: can you provide more complete citation information? What publication was this in?]

44 Socialdemokraterna, Miljöpartiet \& Vänsterpartiet, En rättvis värld är möjlig - Rödgrön platform för Sveriges säkerhets- och försvarspolitik (18 January 2010), 14. Note the connection between the declaration of solidarity and the Madrid terrorist bombings of 2004 . The Socialist-Green platform was presented at the People and Defense Annual National Conference in 2010. Spokesperson Urban Ahlin clarified that the declaration of solidarity did not challenge the Swedish doctrine. 


\section{The Consequences of Conceptual Stretching}

As noted above, the use of solidarity that carries military implications has been in active in Sweden's official discourse since 2004. However, the public debate and controversy regarding the declaration of solidarity did not start until five years later, when the government put forward the Defense Bill of 2009. This sequence is curious: the introduction of solidarity in the discourse in 2004, conceptual stretching in 2007 and 2008 that made the concept wider and deeper, ratification of the Lisbon Treaty in 2008, and a public controversy about the declaration of solidarity in 2009 and 2010. Despite this controversy, we can note that there was no involuntary defection from the Lisbon Treaty in Robert Putnam's terms, and logically this fit the interpretation that the conceptual stretching provided leeway in policy for different actors. But the timing of the debate is nevertheless interesting.

The declaration has an interesting genealogy. ${ }^{45}$ It is a story of how solidarity replaced neutrality as the key concept in Swedish security doctrine starting around 1992. The traditional policy was challenged mainly by the political Right and the Liberal Party, and the legacy of the Cold War as well as any adjustments to the traditional doctrine of "military non-alignment in peace, for the purpose of neutrality in war" became more of an issue in the political confrontations of the 1990s. Around the turn of the century, the Social Democrats became more open to doctrinal change, and the concept of neutrality was abandoned in the official rhetoric. ${ }^{46}$ After 2004, the conceptual stretching of solidarity commenced (as was discussed above).

One explanation for the relative absence of early public debate could be chalked up to "Euro-skepticism." ${ }^{47}$ Entering the EU was a painful process for the mainly proEU political establishment. It could be argued that the political establishment did not want a disturbing debate about security integration, since the majority of Sweden's population had been reluctant Europeans. However, this simple explanation could be misleading, since developments after Sweden's accession to EU membership in 1995 have normalized the notion of EU membership, and have made it more of an accepted dimension in policy. ${ }^{48}$ Both the Social Democrats and the non-socialist parties have made the EU a central tool in Swedish foreign policy.

45 This story was covered in Magnus Christiansson, "Solidaritet och suveränitet" in Kungliga Krigsvetenskapsakademiens Handlingar och Tidskrift 1 (January/March 2010): 96-106.

46 One example leading up to the security policy of 2002 is Sverker Åström, "Dags att slopa neutraliteten" DN-debatt," Dagens Nyheter (8 February 2000).

47 See Rutger Lindahl, "Den komplexa EU-opinionen," in Mitt i nittiotalet, ed. Sören Holmberg \& Lennart Weibull (Göteborg: SOM Institutet, Göteborgs Universitet, 1996), 371-94. However, Lindahl's conclusion is rather that the Swedish population more than anything else seems confused about the meaning of EU membership.

48 See Sören Holmberg, "EU alltmer accepterat," in Svensk host, ed. Sören Holmberg \& Lennart Weibull (Göteborg: SOM Institutet, Göteborgs Universitet, 2009), 299-314. 
A supplementary explanation is that the relatively consistent negativity towards NATO and solidarity in military terms made the EU the only feasible forum for continued security integration. ${ }^{49}$ While many other European countries could handle military alliance commitments under the rubric of NATO and a military crisis management concept within the EU, Sweden focused only on the EU. This solution was palatable to both the Social Democrats and the non-socialist parties. According to this interpretation, the growing consensus on the EU as an indispensable part of Swedish policy cut short any lines of questioning that moved the EU debate into forbidden policy territory. The EU was the main arena for international cooperation, but it could not be branded as an alliance project in military terms. Nevertheless, in different ways, the development of the doctrine challenges the understanding of solidarity within Swedish security discourse.

Before the conceptual stretching phase from 2004 onwards, the term "solidarity" had never been used with a military connotation. To use the two terms "solidarity" and "military" in the same context does not have any credence in the Swedish Social Democratic Party's discourse. "Solidarity" is used in a civilian context and is, in the words of the poet Gunnar Ekelöf, about "seeing oneself in others." ${ }^{50}$ On the contrary, the traditional amalgamation of terms was always "international solidarity." This concept guided Sweden's foreign policy and aid policy during the Cold War. By adopting an internationalist outlook, an ideological connection could be made between the internal development of a welfare state and the struggle for decent conditions for people in foreign nations. ${ }^{51}$ Furthermore, a central aspect of international solidarity during the Cold War was "justice" (rättvisa). Justice referred not least to economic

49 Political scientist Ulf Bjereld has monitored Swedish public opinion on NATO. One article that covers the trend during the 1990s is Ulf Bjereld, "Trendbrott i svensk Nato-opinion" in Ljusnande framtid, ed. Sören Holmberg \& Lennart Weibull (Göteborg: SOM Institutet, Göteborgs Universitet, 1999), 363-70. However, since the 1990s there has been a slight decrease in skepticism regarding NATO; see Ulf Bjereld, "Nu minskar motståndet mot Nato-medlemskap," Dagens Nyheter (4 April 2009).

50 Gunnar Ekelöf, Natt i Otoĉac (Stockholm: Bonniers, 1961). The phrase is also a point of departure for Sven-Eric Liedman; see Sven-Eric Liedman, Att se sig själv i andra: Om solidaritet (Stockholm: Albert Bonniers Förlag, 1999).

51 However, the idea that "solidarity between the small states would seem to be the only effective measure against the arrogance of the great powers" is arguably older than Social Democracy. See Arne Ruth, "The Second New Nation: The Mythology of Modern Sweden" Dadalus 113:2 (Spring 1984): 69. Ever since the inter-war period, "the policy of internationalism has indeed had the status of national ideology in Sweden. It has become an integral part of the mythology of the Swedish model. Equality at home and justice abroad have come to be regarded as complementary and mutually supportive values." Ruth, "The Second New Nation," 71. 
conditions, but it was also used to underline the right to self-determination for all peoples. ${ }^{52}$ This latter interpretation came to amalgamate international solidarity with the defense of international law. The argument is plainly that Social Democracy is embedded in an ideological cosmology in which "international solidarity," "justice," and "international law" are inter-connected concepts. ${ }^{53}$ This is likely to be one of the most durable ideological inheritances from the late Swedish Prime Minister Olof Palme.

Quite on the contrary, the non-socialist political parties do not have any traditional attachment to the notion of "solidarity." The term did not have the same meaning in these parties' discourse, nor did it have any place in their political language. When used in discourse today, "solidarity" is often closely associated with Europe and the EU. ${ }^{54}$ From this perspective, solidarity is a natural consequence of Sweden's membership in the EU, as well as a result of political declarations about closer defense cooperation among the Nordic states. The declaration of solidarity, it has been said, has not created a new situation, but has rather confirmed something that was already established. ${ }^{55}$

As was discussed above, the current status of solidarity in the Swedish political discourse is that of a heterotopia. ${ }^{56}$ Most actors like the notion, but for very different reasons. This makes it apparent that the Swedish declaration of solidarity does not have any clear meaning in Sweden's security policy discourse.

52 In the words of Olof Palme, "We have condemned intervention and interference in the internal affairs of other states... As a small state we have as our goal a world in which the principles of sovereignty and non-intervention are fully respected." See Olof Palme, "Sweden's Role in the World," in Sweden: Choices for Economic and Social Policy in the 1980s, ed. Bengt Rydén \& Willy Bergström (London: Allen \& Unwin, 1982), 244-45.

53 One clear example of the links in this cosmology is found in Olof Palme's speech at the Stockholm Workers Commune, 12 January 1980.

54 An early example includes Ann-Sofie Dahl, "Nato är ett solidaritetsprojekt," Svenska Dagbladet (18 September 2001). More recent examples include Marit Paulsen, Cecilia Malmström, and Carl Bildt, at http://www.folkpartiet.se/Vara-politiker/Ledamoter-av-Europaparlamentet/Marit-Paulsen/Artiklar/Det-handlar-om-solidaritet/; Cecilia Malmström, "Tal om Global solidaritet," speech at the Congress of the Liberal Party; and Carl Bildt, at http://carlbildt.wordpress.com/2007/07/24/europeisk-solidaritet/. As Sweden's Foreign Minister, Carl Bildt used solidarity as the key concept for dealing with the financial crisis in Greece 2010. See SVT Aktuellt (6 May 2010).

55 Stated by defense analyst Robert Dalsjö at the launch of Trovärdig solidaritet?, Hotel Sheraton, Stockholm, January 2010.

56 "Heterotopia" is a term elaborated by Michel Foucault in his work The Order of Things. In this context, it could describe a political ideal with many meanings. Regarding the use of "heterotopia" in international relations, see James Der Derian, "Critical Encounters in International Relations,” International Social Science Journal 191 (March 2008): 71. 
The ideological caveats are indeed different: for left-wingers, solidarity is a civilian term with no strings attached; for the non-socialists, it is a logical continuation of the implications of EU membership. ${ }^{57}$ Thus, the established phrase "security is built in cooperation with others" has a built-in ideological ambiguity. There is great difference in interpretation between a leading Social Democrat who claims that the declaration of solidarity does not mean anything new in military terms, and the top bureaucrat at Sweden's Defense Ministry, who claims that the declaration of solidarity represents a historical point of refraction, and the open activism represented by certain Liberal Conservatives. ${ }^{58}$ This central component of the doctrine could thus potentially become problematic in a situation when solidarity has to be realized in practice.

57 A similar interpretation of the term is made by Claes Roxbergh, Åsa Domeij, \& Maria Wetterstrand, "Solidariteten är vår grundpelare," Dagens Nyheter (1 March 2002).

58 The foreign policy spokesperson for the Social Democrats Urban Ahlin, Johan Raeder of the Defense Ministry, and the parliamentarian for the Moderate Party Göran Lennmarker fit these descriptions. A key article is Johan Raeder, "Solidaritetsförklaringen och dess betydelse," Promemoria Försvarsdepartementet (11 November 2009). 


\section{The Sovereignty Dimension}

\section{The Legal and Symbolic Arsenal of Sovereignty}

This section of the article will focus largely on how Swedish defense and security discourse deals with the tasks that relate to national defense. The traditional role for the armed forces in Sweden was always connected with these tasks. However, ever since the mid-1990s, the armed forces have been undergoing a series of reforms with the explicit purpose of adapting them to the strategic environment of the twenty-first century. In this respect, Sweden is deeply integrated in a transformation process that is recognized in large parts of Europe. This process started during the 1990s, and has been marketed with Anglo-Saxon slogans regarding the role of defense capabilities such as "Go out of area or out of business" and "Use it or lose it." 59 The aim for the development of the Swedish armed forces is to become a flexible operations/defense force (flexibelt insatsförsvar). ${ }^{60}$

Nevertheless, the tasks for the armed forces include the capacity to act without foreign support related to national security. Hence, we can note that the Defense Bill of 2009 states, "Thus, the Government does not exclude that Sweden alone will need to handle threats to our security where the military defense is concerned. Accordingly, such capability must exist." ${ }^{1}$

The transformation of the armed forces toward a focus on availability and flexibility is coupled with a parallel consideration of upholding military capabilities that could also be used solely for unilateral military defense. The armed forces still has the task to defend Sweden without foreign assistance. ${ }^{62}$

Interestingly, this task is a key aspect of the very purpose of Swedish defense policy. The argument has two components: security and sovereignty. According to the government, security is defined as a means to achieve a number of ends. In the Defense Bill of 2009 it is claimed that: "The maintenance of our country's sovereignty is a precondition for Sweden to achieve the aims of our security." ${ }^{63}$

59 In the Swedish context the term "adaptation" (omställning) is often chosen. See Sten Tolgfors, "Utgångspunkterna för den framtida inriktningen av försvaret," Dagens Nyheter (10 June 2008).

60 The formal process for this could be traced in the following propositions: Regeringen, Förändrad omvärld - omdanat försvar Prop. 1998/99:74; Regeringen, Det nya försvaret Prop. 1999/2000:30; and Regeringen, Fortsatt förnyelse av totalförsvaret Prop. 2001/02:10.

61 Prop. 2008/09:140, 34.

62 Ibid., 36.

63 Ibid., 14. 
Note the grammatical mixture in the sentence; there is a distinction between the sovereignty of the country and the aims of security. However, the two concepts are linked, as sovereignty is presented as a precondition for security. The Defense Commission of 2008 had already placed a focus on "Swedish sovereignty," and on the idea that maintaining sovereignty served as a means to the aims of security. ${ }^{64}$

The official doctrine regarding defense cooperation is that there are no limits on what is allowed, as long as Sweden's national sovereignty is kept inviolate. ${ }^{65}$ The government has sometimes argued for common capability development in the Nordic context, while maintaining the separability of Swedish military units and capabilities. ${ }^{66}$

The interpretation of this discursive pattern is crucial. In the Defense Bill of 2009, sovereignty is defined according to its "established meaning in international law." 67 The combination of the key tasks of defending the country without foreign help, maintaining singular military capabilities, and preserving sovereignty as a precondition for security could be interpreted as a reassurance of the value of Sweden's traditional national defense system.

One could get the impression that the nation-state will continue to remain (unilaterally) on guard against any future threats to the territory. Thus, one interpretation of the sovereignty dimension is that the connections between defense, sovereignty, and security serve as a chain of linked concepts that deal with the traditional function of military defense. A major function of this game surrounding the construction of a domestic image of the centrality of national sovereignty is that the government can maintain an ideal of independence rather than interdependence.

However, the use of the term "sovereignty" is also marked with other connotations. The Swedish government's use of the term is far from uniform. The Defense Bill of 2009 elaborates on the subject as follows: “... strategic development[s] in our immediate surroundings lead to a need for a military capability for proactive national action to promote the aims of our security, Swedish sovereignty, sovereign rights, and national interests." 68

${ }^{64}$ Ds 2008:48, p. 26, 39 and 48.

65 Stated, twice, by Defense Ministry official Peter Göte at the XIII Suomenlinna Seminar, in June 2010. This has been the official position since the time of Defense Minister Mikael Odenberg.

66 Sten Tolgfors, "Gemensamma förband med Norge en lösning," Dagens Nyheter (10 June 2008).

67 Prop. 2008/09:140, 34.

68 Ibid., 33. 
This notion of a "military capability for proactive national action" is not traditionally linked to sovereignty. The traditional function of territorial defense was reactive rather than proactive with respect to foreign aggression. Furthermore, the Defense Bill of 2009 clarifies that the precondition for security - that is, sovereignty-is not enough on its own to achieve the aims of security: "The aim of military defense is not achieved only through the maintaining of the country's borders and territorial integrity." ${ }^{69}$ And accordingly, during the confusing debate about the declaration of solidarity in the autumn of 2009, the government made a clarification: "The defense of Sweden shall not only be conducted within our borders." 70

Thus, the precondition for security is also achieved through proactive actions on the part of the national military. Nonetheless, this is not enough to achieve the aims of military defense - as the government stated in 2009, defense of Sweden should also be conducted beyond Sweden's borders. To draw an analogy (but actually one with a completely reversed direction), Sweden must also be prepared to develop military capabilities in the context of international cooperation: "Capabilities that first have a national direction and are considered to be demanded in a long-term perspective should be evaluated from the possibility of finding solutions based on international cooperation which leads to maintenance with limited resources." 71

In this interpretation, sovereignty and defense are not linked exclusively to national concerns. Proactive military actions necessary for security could be carried out in other countries, as well as together with other countries. The capabilities to maintain the preconditions for security are created together with other countries. Sovereignty and defense are linked via international cooperation. This is a de facto recognition of interdependence rather than independence.

\section{Sovereignty as a National or International Concern}

The context for the different meanings of the term "sovereignty" used by the Swedish government must be taken into consideration. Developments after the end of the Cold War have been marked mainly by two major changes in the official Swedish security policy discourse: how threats are defined, and how the role of the armed forces is viewed. These changes are notable in the sense that they represent the official discourse; other perspectives tend to be alternatives to the official system of statements on security policy.

\footnotetext{
69 Prop. 2008/09:140, 35.

70 Raeder, "Solidaritetsförklaringen och dess betydelse," 4.

71 Prop. 2008/09:140, 54.
} 
The changing construction of threats is related to the growing tendency of "Europeanization," which many scholars have discussed. ${ }^{72}$ As noted above, the European Union became central to many Swedish security initiatives in the 1990s. Furthermore, the full meaning of "Europeanization" in the Swedish case is that the analytical category of power politics is very weak, marginalized, or absent in official documents. Instead, there is a clear tendency to emphasize a wider security concept. ${ }^{73}$ The Swedish government hardly elaborates on power politics in the Nordic-Baltic context. ${ }^{74}$ This change is visible in the Swedish government's stance toward a newly assertive Russia. Sweden's policy during the decade after the Soviet collapse seems to have been dictated by the balance between democratic critique and encouragement, an act that did not change much between the Social Democratic and the more conservative governments. However, since Russia under Vladimir Putin (and now Dmitry Medvedev) has acted in ways that depart from the assumptions of Europeanization, the Swedish government has developed a differentiated view of its Eastern neighbor: one that on the one hand is flexible in order to accommodate uncertainties in Russia's development, while on the other hand provides policy space for continued faith in Europeanization. After the crisis in Georgia in August 2008, this diversification became visible in a clear way. According to the Swedish government, the Russia that

72 In research, the term "Europeanization" covers a condition "when something in the domestic political system is affected by something European." See Maarten Vink, "What is Europeanization? and Other Questions on a New Research Agenda," paper for the Second YEN Research Meeting on Europeanization,

University of Bocconi, Milan (22-23 November 2002). This argument is elaborated in the context of Swedish defense policy by Arita Eriksson, Europeanization and Governance in Defence Policy: The Example of Sweden (Stockholm: Stockholm University, 2006).

73 Explicitly in Regeringen, Totalförsvar i förnyelse - etapp 2 Prop. 1996/97:4, 21.

74 Expressed by a senior official from the Swedish Foreign Ministry at a closed diplomatic conference at the Estonian Embassy, February 2010. This is a general tendency in the Nordic region, as emphasized in Olav F. Knudsen, "Looking to the Future: Security Strategies, Identity, and Power Disparity," in Security Strategies, Power Disparity and Identity, ed. Olav F. Knudsen (Aldershot, U.K.: Ashgate, 2007), 180. 
conducts military incursions in the Caucasus is something different from the Russia that acts in the Baltic Sea region or the Arctic region. ${ }^{75}$

The defense implications for Sweden related to the uncertainties in Russia provide a clear illustration of the second fundamental change: the role of the military instrument. During the Cold War, the role of military defense in Sweden was that of insurance. The rhetoric of this stance is quite elegant: an insurance premium had to be paid to create safety if an accident should happen. The central element of this metaphor is that there is no intention to ever actually make a claim on the insurance; to pay for security was a routine that did not entail any active service in return. Military capabilities had an inherent value in themselves, because they could be one of the factors that stopped a military attack from occurring. The fundamental function of a military force was connected to deterrence against foreign powers. According to this logic, the correct reaction to insecurity would be to strengthen one's credible capabilities for deterrence. The major change in the defense debate after the Cold War is that military forces are no longer considered to have a value in themselves. The development of a flexible operations/defense capability means creating more available military units. Thus, a consequence of this reasoning is that military systems that for some reason do not have high availability lose value and priority. ${ }^{76}$

However, these two discursive shifts are far from uncontested. There are several influential critics who argue for the continued relevance of power politics, as well as the deterrent role of military forces. The underlying point of departure for the analysis is this: What happens if Russia becomes a major power that once again poses a military threat to Sweden? The implicit and explicit military concern behind this question is, Can Sweden defend itself? According to these staunch critics, Sweden is making hardly any preparations to take on a major confrontation single-handedly.

75 Before the Georgian crisis of August 2008, the Defense Commission declared that "the Russian actions towards countries that used to be a part of the Soviet Union will be a litmus test for the path Russia is taking," and that "Russia's relationship and actions towards these countries will define our view of Russia. The solidarity between Nordic and EU states is important in this respect." Quoted in Ds 2008:48, 23. The Defense Bill was delayed because of the Georgian crisis. See Mikael Holmström, "Försvarsbeslut kommer först nästa år," Svenska Dagbladet (9 September 2008). After the Georgian crisis, the Swedish government concluded that Russia's willingness to use force "varies with the political and strategic situation in each case," and that the "willingness to take political risks and the willingness and ability to act militarily is much higher towards CIS-countries than countries that are members of the EU and NATO." Quoted in Prop. 2008/09:140, 24.

76 See for example Ds 2008:48, 14. 
There is a tension among defense supporters of the old guard, who tend to criticize Sweden's lack of capabilities for national defense. ${ }^{77}$

These somewhat overlooked consequences of Europeanization (and its counterreaction) make it much easier to understand the varying senses of "sovereignty" used by the government in the Defense Bill of 2009. On the one hand, there is a need to assure a domestic audience that Sweden's sovereignty is secured by Swedish might alone, which means that it essentially is a national concern. However, both the Social Democratic and the current non-socialist governments argue that Sweden should not focus exclusively on territorial defense, even if its current defense capabilities should be maintained. Therefore, on the other hand there is a need to introduce the domestic audience to the notion that sovereignty is secured in cooperation with others, which means that it is also an international concern.

Some critics have pointed out that this line of reasoning is built on the assumption that foreign powers will always come to Sweden's aid in times of trouble, and that this could represent a form of wishful thinking should a crisis erupt in the Baltic Sea region, which would most likely involve Russia. Analysts have also pointed out that Sweden's capacity to receive foreign military aid has largely been neglected. ${ }^{78}$

Be that as it may, the main point is that the invocation of "sovereignty" in the Swedish marks a point of fundamental national concern, while it also serves ambitions for further international cooperation. Sovereignty can be not only "established," "Swedish," and a point of departure, but also "proactive," and resting on international cooperation. There are two related consequences from this: the dual uses of sovereignty obscure its meaning within Swedish security doctrine, and the domestic audience has a hard time figuring out how to act upon it.

An example of this obscurity is the aim to maintain the separability of Swedish military units from multilateral forces. On the one hand, it could be argued that national military capabilities are what give sovereignty its very meaning. There is no point in stressing sovereignty as a requirement in international cooperation if one does not have any units to command.

77 For critical remarks regarding a national reserve, see Olof Santesson, "Försvara landet med ett kompani. Mellan nätverkets löften och krigets väsen," in Kungliga Krigsvetenskapsakademiens Handlingar och Tidskrift 2 (2007): 99-106. For critical remarks on the lack of national defense capabilities, see Lars Bergquist, Carl Björeman, \& Karl Erik Lagerlöf, "Bildt driver en farlig utrikespolitik," Svenska Dagbladet (3 February 2008); and Bo Pellnäs, "Sveriges trovärdighet är i fara," Svenska Dagbladet (18 January 2009).

78 See, for example, Hugemark \& Tunberger, Trovärdig solidaritet?, 26-27; Bo Ljung \& Karlis Neretnieks, Nordisk försvarspolitisk samverkan - fortsättningsstudie. Strategiska mål och operativ - nationella eller gemensamma? (Stockholm: FOI, R-2734-SE, 2009); and Wilhelm Agrell, Fredens illusioner. Det svenska nationella försvarets nedgång och fall 1988-2009 (Stockholm: Atlantis, 2010). 
On the other hand, the ambitions of Swedish defense go beyond the nation's borders, and its sovereignty partly relies on the status of others.

These remarks are not just hypothetical considerations. Actors in the domestic audience find it difficult to act on these different signals. For example, when the Swedish armed forces conducted a relatively small-scale exercise for the local defense of Gotland in September 2009, the responsible general gave explicit instructions that all orders should be given in Swedish. ${ }^{79}$ Was this right or wrong? If Sweden should be able to handle military threats on its own, it might seem reasonable. However, if its capabilities for national defense are to be developed within frameworks of international cooperation, and if the defense of Sweden also takes place across the Baltic Sea, then it might be problematic. (One could also note that the general's decision suddenly nullified more than a decade of preparations for "interoperability.")

\section{The Two-Dimensional Game of Solidarity and Sovereignty}

The purpose of this article is to examine how we can understand a militarily nonaligned country that declares military solidarity with its neighboring countries. The perspective of two-dimensional games has showed us this "ambiguity at work," as the saying goes. ${ }^{80}$ As we have seen, the conceptual stretching of solidarity has created a heterotopia in Swedish security policy. Different actors can invoke "solidarity" for quite different purposes, both as a sign of Sweden's active involvement in the processes of Euro-Atlantic integration and as a notion that is fully compatible with the status quo preference for military non-alliance. We have also studied the differentiated use of the term "sovereignty" by the Swedish government. It becomes understandable how "sovereignty" can simultaneously mean self-reliance and interdependence when it is viewed in the context of the Swedish defense debate.

The use of a two-dimensional game approach challenges the established perspective of security integration as a process of socialization in the EU context. ${ }^{81}$ According to the theory of socialization, an integration process potentially moves a discourse within a country from instrumental adaptation to a change in security identity and learning. This idea is based on the assumption that a change of identity is necessary for a stable and long-term change in security approach. ${ }^{82}$

79 This refers to "Exercise Dagny".

80 Hanna Ojanen, Gunilla Herolf, \& Rutger Lindahl, Non-Alignment and European Security Policy: Ambiguity at Work. (Helsinki and Bonn: Ulkopoliittinen instituutti and Institut für Europäische Politik, 2000).

81 This argument is applied to the Nordic context in Pernille Rieker, "Europeanization of Nordic Security," Cooperation \& Conflict 39:4 (December 2004): 369-92.

82 Pernille Rieker, "From Nordic Balance to Europeanisation? The EU and the Changing Security Identities of the Nordic States," paper prepared for "Fagkonfereanse for NFE," (28-29 August 2003), 19. 
Thus, international integration demands adjustments in identity. ${ }^{83}$ Accordingly, changes in a discourse become one-dimensional, and Sweden has been described as having "undergone a more stable and enduring change in security policy" when compared to its Nordic neighbors. ${ }^{84}$

However, this one-dimensional learning perspective makes it difficult to explain the peculiarities of the Swedish case. If there really is a change of identity, and learning has happened, why is the idea of collective security within the European framework still so controversial in Sweden? If the Lisbon Treaty was fully integrated into Sweden's security identity, why is the meaning of "solidarity" so multiplied and problematic? Or, furthermore, why does Swedish membership in NATO seem just as unlikely today as it did twenty years ago?

It seems fair to say that the theory of socialization provides us with a narrow view of a strategic culture. Such a one-dimensional perspective fails to comprehend the full range of rhetorical flexibility of the political terminology that is under study. It might be that the security policy discourse in Sweden has become more uniform, but as this study has shown, the process of conceptual stretching makes it possible to use the same discourse for audiences with potentially different preferences.

One of the major advantages to using the approach of two-dimensional games is that it becomes easier to understand the peculiarities of the Swedish case. Instead of having the idea that Swedish officials have become socialized to shift from neutrality to a Euro-Atlantic discourse, it becomes easier to follow the use of terms like "solidarity" and "sovereignty" if applied in a game framework. Rather than challenging public opinion in the security and defense area, a sophisticated discursive game has been developed to stretch the meaning of solidarity and sovereignty.

83 Regina Karp, "The Conditionality of Security Integration: Identity and Alignment Choices in Finland and Sweden" in Security Strategies, Power Disparities, and Identity, ed. Olav F. Knudsen, 70.

84 Rieker, "Europeanization of Nordic Security," 385. 


\section{Bibliography}

Adler-Nissen, Rebecca, and Thomas Gammeltoft-Hansen. "An Introduction to Sovereignty Games." In Sovereignty Game: Instrumentalizing State Sovereignty in Europe and Beyond. New York: Palgrave Macmillan, 2008.

Arvidsson, Claes. "En värld - två alternative." Svenska Dagbladet (2010).

Echoes of the Holocaust: Historical Cultures in Contemporary Europe. Lund:Nordic Academic Press, 2003.

Eliasson, Johan. "Traditions, Identity and Security: The Legacy of Neutrality in Finnish and Swedish Security Policies in Light of European Integration." European Integra tion online Papers 8, no. 6 (2004): 13.

Gadamer, Hans-Georg. Truth and Method . New York: Continuum, 1993.

Glenn, John, Darryl Howlett, and Stuart Poore. Neorealism Versus Strategic Culture. Aldershot, U.K.: Ashgate, 2004.

Holmström, Mikael. "Försvarets bantning ger stort manfall." Svenska Dagbladet (2004).

Hugemark, Bo. "Sverige måste kunna försvara sina grannar." Svenska Dagbladet (2009).

Lantis, Jeffrey S., and Darryl Howlett. "Culture and National Security Policy." In Strategy in the Contemporary World. Oxford: Oxford University Press, 2010.

Neumann, Iver B., and Henrikki Heikka. "Grand Strategy, Strategic Culture, Practice." Cooperation \& Conflict 40, no. 1 (2005): 11.

Poore, Stuart. "What Is the Context? A Comment on the Gray-Johnston Debate on Strategic Culture." Review of International Studies (2003): 279-84.

Putnam, Robert D.. "Diplomacy and Domestic Politics: The Logic of Two-level Games." International Organization 42, no. 3 (1988): 427-60.

Wetterstrand, Maria, Åsa Domeij, and Claes Roxbergh. "Solidariteten är vår grundpelare." Dagens Nyheter (2002). 